\title{
Boron Accelerates Cultured Osteoblastic Cell Activity through Calcium Flux
}

Mark Luigi Fabian Capati Ayako Nakazono Kazunari Igawa' Kensuke Ookubo Yuya Yamamoto Kajirou Yanagiguchi Shisei Kubo Shizuka Yamada Yoshihiko Hayashi*

Department of Cariology, Nagasaki University Graduate School of Biomedical Sciences, Nagasaki 852-8588, Japan

*Corresponding author

e-mail: hayashi@nagasaki-u.ac.jp

The first two authors contributed equally to this work. 


\begin{abstract}
A low concentration of boron (B) accelerates the proliferation and differentiation of mammalian osteoblasts. The aim of this study was to investigate the effects of $0.1 \mathrm{mM}$ of $\mathrm{B}$ on the membrane function of osteoblastic cells in vitro. Genes involved in cell activity were investigated using gene expression microarray analyses. The $\mathrm{Ca}^{2+}$ influx and efflux were evaluated to demonstrate the activation of L-type $\mathrm{Ca}^{2+}$ channel for the $\mathrm{Ca}^{2+}$ influx, and that of $\mathrm{Na}^{+} / \mathrm{K}^{+}-\mathrm{ATPase}$ for the $\mathrm{Ca}^{2+}$ efflux. A real-time PCR analysis revealed that the mRNA expression of four mineralization-related genes was clearly increased after 3 days of culture with a B-supplemented culture medium. Using microarray analyses, five genes involved in cell proliferation and differentiation were up-regulated compared to the control group. Regarding the $\mathrm{Ca}^{2+}$ influx, in the nifedipine-pretreated group, the relative fluorescence intensity for one min after adding $\mathrm{B}$ solution did not increase compared with that for one min before addition. In the control group, the relative fluorescence intensity was significantly increased compared with the experimental group $(P<0.05)$. Regarding the $\mathrm{Ca}^{2+}$ efflux, in the experimental group cultured in $0.1 \mathrm{mM}$ of B-supplemented medium, the relative fluorescence intensity for 10-min after ouabain treatment revealed a significantly lower slope value compared with the control group $(P<0.01)$. This is the first study to demonstrate the acceleration of $\mathrm{Ca}^{2+}$ flux by $\mathrm{B}$ supplementation in osteoblastic cells. Cell membrane stability is related to the mechanism by which a very low concentration of $B$ promotes the proliferation and differentiation of mammalian osteoblastic cells in vitro.
\end{abstract}


Key words Boron $\cdot$ Odontoblast $\cdot$ Cell proliferetion $\cdot$ Differentiation $\cdot \mathrm{Ca}^{2+}$ flux

Introduction 
A previous report that boron (B) can improve bone mineralization in chicks with dietary deficiency [1] first demonstrated that $B$ is beneficial and essential for higher animals. Analyses of both human and animal data suggested that an acceptable safe range of B intake for adults could be 1-13 $\mathrm{mg} / \mathrm{d}$ [2]. Furthermore, B was identified as a nutritionally important element throughout the life cycle [3]. Dietary B may be beneficial for optimal calcium metabolism and, as a consequence, optimal bone metabolism [4, 5]. Boron supplementation in rats and chicks has been shown to increase bone strength, and may also play a role in improving arthritis, plasma lipid profiles, and brain function [6]. Moreover, dietary B deprivation in mice has been shown to alter periodontal alveolar bone modeling and remodeling by inhibiting bone formation [7].

$\mathrm{Ca}^{2+}$ signaling and homeostasis related to $\mathrm{B}$ supplementation or deprivation have been widely investigated in plants [8,9] compared with mammals. The activity of $\mathrm{Ca}^{2+}$ channels, pumps and transporters is responsible for generating the influx and efflux of $\mathrm{Ca}^{2+}$, which regulate its homeostasis. Cyclic nucleotide-gated ion channels, autoinhibited $\mathrm{Ca}^{2+}$ ATPase and cation $/ \mathrm{H}^{+}$exchanger proteins are involved in this process $[10-$ 12]. Furthermore, elevated intracellular $\mathrm{Ca}^{2+}$ has been reported to stimulate MAPK activity in several mammalian cell lines [13-15].

A very low concentration of $B$ accelerates the proliferation and differentiation in mammalian osteoblastic cells in vitro [16, 17]. However, the mechanisms of these phenomena are still not well understood. The aim of this study was to investigate the effects of $B$ on the membrane function of 
osteoblastic cells in vitro. After the expression of calcification-related genes associated with $\mathrm{Ca}^{2+}$ metabolism in the hard tissue was analyzed using realtime PCR in osteoblastic cells under B supplementation, the genes involved in cell activity were investigated using gene expression microarray analyses. Finally, the $\mathrm{Ca}^{2+}$ influx and efflux were evaluated to demonstrate the activation of the L-type $\mathrm{Ca}^{2+}$ channel for the $\mathrm{Ca}^{2+}$ influx, and that of $\mathrm{Na}^{+} / \mathrm{K}^{+}-$ ATPase for the $\mathrm{Ca}^{2+}$ efflux.

\section{Materials and Methods}

Cell Culture for Passage

Osteoblastic cells (NOS-1 cells [18]) derived from human osteosarcoma were used in the present study. They were seeded in a $60-\mathrm{mm}$ culture dish at a density of $5 \times 10^{5}$ cells in $\alpha$-MEM (Gibco, Palo Alto, CA, USA) supplemented with 10\% fetal bovine serum (FBS) (MP Biomedicals, Santa Ana, CA, USA) and $0.01 \%$ penicillin-streptomycin (Life Technologies), and then were cultured in a humidified incubator at $37^{\circ} \mathrm{C}$ in an atmosphere of $5 \% \mathrm{CO}_{2}$ and air. The medium was changed every 3 days.

Preparation of Boron Solution

Boric acid was purchased from Wako (Osaka, Japan). A $100 \mathrm{mM}$ solution of B was prepared by dissolving powdered boric acid in $\alpha$-MEM without FBS. 
The completely dissolved solution was filtered using a $0.2 \mu \mathrm{m}$ filter as a stock solution.

Total RNA Isolation for Real-time PCR and Microarray

NOS-1cells were seeded in a $60-\mathrm{mm}$ culture dish at a density of $7 \times 10^{4}$ cells $/ \mathrm{cm}^{2}$ in $\alpha$-MEM without FBS. A $0.1 \mathrm{mM} \mathrm{B}$ was used for all experiments in this study, because our basic experiments indicated that a $0.1 \mathrm{mM}$ of $\mathrm{B}$ was suitable for the proliferation of NOS-1 cells [19]. After 3 days of culture with or without a $0.1 \mathrm{mM}$ of $\mathrm{B}$, total RNA from cells were isolated using TRIzol reagent $\left(1 \mathrm{~mL} / 10 \mathrm{~cm}^{2}\right)$ (Invitrogen, Carlsbad, CA, USA), and purified using the SV Total RNA Isolation System (Promega, Madison, WI, USA) according to the manufacturer's instructions.

Real-time PCR for Mineralization-related Genes

Real-time PCR was used to detect the expression of four mineralizationrelated genes, alkaline phosphatase (ALP), osteopontin (OPN), osteocalcin $(\mathrm{OCN})$, and bone sialoprotein (BSP). cDNA synthesis and amplification via PCR were performed using the SuperScript ${ }^{\mathrm{TM}}$ First-Strand Synthesis System (Invitrogen) and an oligo dT primer. cDNA obtained from $400 \mathrm{ng}$ of total RNA was used for one PCR. For each real-time PCR sample, a master mix of the following reaction components was prepared at the indicated quantities: $9.1 \mu 1$ of water, $0.3 \mu 1$ of diluted reference dye, $0.2 \mu 1$ of forward and reverse 
primers (Table 1) and $10 \mu$ l of Brilliant ${ }^{\circledR}$ SYBR $^{\circledR}$ Green QPCR master mix (Stratagene, La Jolla, CA, USA). The above-mentioned reaction was placed in a $0.2 \mathrm{ml}$ tube and $0.2 \mu 1$ of cDNA was added as the PCR template. The PCR sequence protocol was as follows: denaturation $\left(94^{\circ} \mathrm{C}, 1 \mathrm{~min}\right)$ followed by 40 cycles of amplification and quantification $\left(56^{\circ} \mathrm{C}, 1 \mathrm{~min}\right)$ and a final extension $\left(72^{\circ} \mathrm{C}, 1 \mathrm{~min}\right) . \quad$ Amplification and data acquisition were performed using an Mx3000P QPCR machine (Stratagene).

Quantification was accomplished by determining the threshold cycle (the second derivative of the resulting fluorescence curve) at which the amplicon is detected during PCR and then comparing this to the standard curve calculated from the parallel quantification reactions. These calculations were performed with the comparative quantification method using the Stratagene form. These data were normalized by glyceraldehyde phosphate dehydrogenase (GAPDH).

Gene Expression Microarray for Proliferation and Differentiation

The cRNA was amplified, labeled using GeneChip ${ }^{\circledR}$ WT Terminal Labeling and Control Kit (Affymetrix, Santa Clara, CA, USA), and hybridized to an Affinity Human Genome U133 Plus 2.0 array (for 47,000 transcriptional products) according to the manufacturer's instructions. All hybridized microarrays were scanned by an Affymetrix scanner. Relative hybridization intensities and background hybridization values were calculated using the Affymetrix Expression Console $\mathrm{T}^{\mathrm{TM}}$. 
Data Analysis and Filter Criteria

The raw signal intensities for each probe were calculated from hybridization intensities. The raw signal intensities of two samples were $\log _{2}$-transformed and normalized by RMA and quantile algorithm [20] with Affymetrix ${ }^{\circledR}$ Expression Console ${ }^{\mathrm{TM}} 1.1$ software. To identify up-regulated genes, Z-scores [21] from ratios (non-log scaled original fold-change) were calculated from the normalized signal intensities of each probe for comparison between control and experiment samples. Then, we established the criterion for the up-regulated genes $(Z$-score $>2.0)$.

Real-time PCR after Microarray

The NOS-1 cells were seeded and cultured under the same conditions as those in the experiment for calcification-related genes. The protocols for RNA extraction, cDNA synthesis, and PCR were similar to the above-mentioned methods. Primer's sequences of the target genes were listed in Table 2 .

Cell Culture for $\mathrm{Ca}^{2+}$ Flux Studies

In the $\mathrm{Ca}^{2+}$ influx study, the NOS-1 cells were cultured in a $35 \mathrm{~mm}$ glassbottom culture dish (FluoroDish, World Precision Instruments, Sarasota, FL, USA) at a density of $3 \times 10^{5}$ cells in $\alpha$-MEM without FBS and B for 3 days. 
For the L-type $\mathrm{Ca}^{2+}$ channel blocker-applied group, nifedipine (final concentration of $10 \mu \mathrm{M}$ ) was added to $\alpha$-MEM and cultured for $30 \mathrm{~min}$ before Fluo 4-AM loading. The control group was incubated in $\alpha$-MEM containing solvent, ethanol at a final concentration of $0.05 \%$. In the $\mathrm{Ca}^{2+}$ efflux study, the NOS-1 cells were cultured in a $35 \mathrm{~mm}$ glass-bottom culture dish (FluoroDish) at a density of $6 \times 10^{5}$ cells in $\alpha$-MEM without FBS for 3 days. In the $\mathrm{Na}^{+} / \mathrm{K}^{+}$-ATPase-activated group, B solution at a final concentration of $0.1 \mathrm{mM}$ was added to $\alpha$-MEM. The control group was incubated in only $\alpha-$ MEM.

Fluo 4-AM Loading

The cells were loaded with Fluo 4-AM (DOJINDO LABORATORIES, Kumamoto, Japan) by incubation with a low sodium HEPES assay buffer (5 $\mathrm{mM} \mathrm{NaCl}, 135 \mathrm{mM}$ choline chloride, $10 \mathrm{mM}$ HEPES, $5 \mathrm{mM} \mathrm{KCl,} 1 \mathrm{mM} \mathrm{MgCl}$, $10 \mathrm{mM}$ glucose), $0.5 \%$ Fluo 4 -AM in DEMSO, $1.25 \mathrm{mM}$ probenecid, and 0.04\% Pluronic F-127 (BASF SE, Ludwigshafen, Germany) in a 5\% $\mathrm{CO}_{2}$ incubator for $15 \mathrm{~min}$.

\section{Confocal Laser Microscopy}

In the $\mathrm{Ca}^{2+}$ influx experiment, Fluo 4 -AM loaded cells in a $35 \mathrm{~mm}$ glassbottom culture dish were covered with $990 \mu \mathrm{L}$ of recording buffer $(115 \mathrm{mM}$ $\mathrm{NaCl}, 20 \mathrm{mM}$ HEPES, $5.4 \mathrm{mM} \mathrm{KCl}, 0.8 \mathrm{mM} \mathrm{MgCl}_{2}, 1.8 \mathrm{mM} \mathrm{CaCl}_{2}, 13.8 \mathrm{mM}$ 
glucose) and $1.25 \mathrm{mM}$ probenecid for fluorescence observation of $\mathrm{Ca}^{2+}$ influx using a confocal laser microscope (TCS SL, Leica Microsystems GmbH, Wetzlar, Germany). The approximate fluorescence excitation/emission maximum for imaging of intracellular $\mathrm{Ca}^{2+}$ was $495 / 518 \mathrm{~nm}$. One min after setting on the microscopic stage, activation of the $\mathrm{Ca}^{2+}$ channel was investigated by adding $10 \mu \mathrm{L}$ of B solution at a final concentration of $0.1 \mathrm{mM}$ into the recording buffer. Fluorescence was scanned every $10 \mathrm{~s}$ and recorded on about 5-6 cells for a total of $1 \mathrm{~min}(\mathrm{n}=3)$. The effect of $\mathrm{B}$ on the $\mathrm{Ca}^{2+}$ influx was examined by comparing the coefficient (slope) of a regression line calculated using the least-squares method in both the experimental and control groups. In the $\mathrm{Ca}^{2+}$ efflux experiment, Fluo 4-AM loading cells were incubated in a $5 \% \mathrm{CO}_{2}$ microscopic stage incubator (H301-TC1-HMTC, Okolab S.r.L., NA, Italy) for 15 min with recording buffer (low sodium HEPES assay buffer, $1.25 \mathrm{mM}$ probenecid, and $0.5 \mathrm{mM}$ ouabain) for fluorescence observation of the $\mathrm{Ca}^{2+}$ efflux using a confocal laser microscope. Fluorescence was scanned every $10 \mathrm{~s}$ and recorded on about 20 cells for a total of $10 \min (n=3)$. The comparison between the experimental and control groups was similarly analyzed using the method described in the $\mathrm{Ca}^{2+}$ influx study.

Statistical Analysis

The data were expressed as the means \pm standard deviation. The differences between the two groups were assessed using the one-tailed Student's t-test. 
Significance was set at a level of $P<0.05$.

\section{Results}

Gene Expression for Mineralization

The real-time PCR analysis revealed that the mRNA expression of four mineralization-related genes, ALP, OPN, OCN, and BSP, was clearly increased after 3 days of culture with $0.1 \mathrm{mM}$ of boron-supplemented culture medium, with average balanced score ratios of $7.1,8.4,1.7$, and 1.6, respectively, compared with the control groups (Fig. 1).

Gene Expression for Proliferation and Differentiation

Using a microarray analysis, 119 of the up-regulated genes (Z-score > 2.0) were confirmed. Among them, five genes craniofacial development protein 1 (CFDP), stromal cell derived factor 4 (SDF4), mitogen-activated protein kinase kinase 1 (MAP2K1), catenin alpha 1 isoform (CTNNA1), and collagen type I alpha 1 (COL1A1), involved in osteoblastic cell proliferation and differentiation processes were furthermore compared with the control group using a real-time PCR (Table 3). Although 96 of the down-regulated genes $(Z$-scores $<-2)$ were confirmed, they were not found to be related to the osteoblastic cell proliferation or differentiation processes. 
The PCR analysis revealed that the mRNAs expression of CFDP, SDF4, MAP2K1, CTNNA1, and COL1A1 was clearly increased after 3 days of culture with $0.1 \mathrm{mM} \mathrm{B}$, with average balanced score ratios of $>1.3$, compared with the control group (Fig. 2).

Acceleration of the $\mathrm{Ca}^{2+}$ flux

Regarding the $\mathrm{Ca}^{2+}$ influx, in the nifedipine-pretreated group, the relative fluorescence intensity for one min after the addition of $10 \mu \mathrm{L}$ of B solution was not increased compared with that for one min before the addition of 10 $\mu \mathrm{L}$ of B solution, and the calculated slope was judged to be zero, including negative values. In the control group, the relative fluorescence intensity for one min after addition of $10 \mu \mathrm{L}$ of $\mathrm{B}$ solution increased compared with that for one min before the addition of $10 \mu \mathrm{L}$ of $\mathrm{B}$ solution, and the calculated slope was $3 \pm 1.7$ (Figs. 3 and 4 ). There was a significant difference between the experimental and control groups $(P<0.05)$.

Regarding the $\mathrm{Ca}^{2+}$ efflux, in the experimental group cultured in $0.1 \mathrm{mM}$ of B supplemented medium, the relative fluorescence intensity for 10 -min after ouabain treatment revealed a significantly lower slope value $(3.3 \pm 0.6)$ compared with the control group $(5.3 \pm 0.6)(P<0.01)($ Figs. 5 and 6$)$.

\section{Discussion}


In the present study, NOS-1 cells accelerated the osteoblastic function after 3-day culture in $0.1 \mathrm{mM}$ of B supplemented medium, which was demonstrated by the increased expression of calcification-related genes. Bone ALP is an early stage marker essential for osteoblast proliferation [22]. OPN, OCN, and BSP are frequently used as markers for osteoblast differentiation [22-24]. These scientific data indicated that the NOS-1 cell line preserves osteoblastic cell characteristics, and a low concentration of B directly stimulates both the proliferation and differentiation pathways in osteoblastic NOS-1 cells.

Microarray and real-time PCR analyses for detecting genes involved in proliferation and differentiation in NOS-1 cells revealed that the z-score data using standard deviations more clearly demonstrated the effect of B on NOS1 cells compared with the original ratio data. Five genes, including one of the intracellular signal transducer genes (MAPK), demonstrated increased gene expressions. To the best of our knowledge, this finding is the first to indicate that B stimulates the intracellular signal pathway through MAPKs. As the intimate relationship between intracellular $\mathrm{Ca}^{2+}$ and MAPKs has been already reported in several cell lines [13-15], we evaluated the effect of $B$ on the intracellular $\mathrm{Ca}^{2+}$ flux to determine the mechanism by which $\mathrm{B}$ activates osteoblasts in this study.

The L-type $\mathrm{Ca}^{2+}$ channel has reported to exist in the cell membrane of osteoblasts [25]. Osteoblast L-type $\mathrm{Ca}^{2+}$ channels are activated by numerous bone regulatory factors, including parathyroid hormone [26-28], vitamin D3 [27, 29, 30], mechanical stimuli [31, 32], ascorbic acid [33], and ALP [34]. Whether B accelerates the L-type $\mathrm{Ca}^{2+}$ channel in osteoblasts has not yet been 
determined. This is the first report to identify the effect of B on the L-type $\mathrm{Ca}^{2+}$ channel in osteoblasts. For this purpose, nifedipine, a specific inhibitor of the L-type Ca channel, was used in this study. Nifedipine slows $\mathrm{Ca}^{2+}$ entry into cardiac and smooth muscle cells by blocking the L-type $\mathrm{Ca}^{2+}$ channel, thereby disrupting the excitation and contraction processes $[35,36] . \mathrm{Ca}^{2+}$ channel blockers prevent $\mathrm{Ca}^{2+}$ influx, and promote osteoblastic differentiation through high membrane retaining ability [37]. In the present study, although B significantly promoted the $\mathrm{Ca}^{2+}$ influx in NOS-1 cells pretreated without nifedipine, it did not accelerate the $\mathrm{Ca}^{2+}$ influx in NOS-1 cell pre-treated with nifedipine. These findings demonstrate that the L-type $\mathrm{Ca}^{2+}$ channel exists in the NOS-1 cell membrane, and a low concentration of B rapidly stimulates this channel. This $\mathrm{B}$ effect on osteoblastic activity most likely promotes cell membrane stability.

According to the effect of $\mathrm{B}$ on cell membrane activity, the $\mathrm{Ca}^{2+}$ efflux was evaluated as osteoblastic cells promote calcification. Ouabain (cardiac glycoside), a commonly used inhibitor of $\mathrm{Na}^{+} / \mathrm{K}^{+}$-ATPase, was used to investigate the effect of $B$. This enzyme catalyzes the coupled active transport of $\mathrm{Na}^{+}$and $\mathrm{K}^{+}$across the plasma membrane as a sodium pump [38, 39]. The effect of ouabain is due to the partial inhibition of $\mathrm{Na}^{+} / \mathrm{K}^{+}$-ATPase, which causes an increase in intracellular $\mathrm{Na}^{+}$, which in turn affects the sarcolemmal $\mathrm{Na}^{+} / \mathrm{Ca}^{2+}$ exchanger and leads to the increase in intracellular $\mathrm{Ca}^{2+}$ as the cause of positive inotropic action [40, 41]. Our study is also the first to identify the effect of $\mathrm{B}$ on $\mathrm{Na}^{+} / \mathrm{K}^{+}$-ATPase activity in osteoblasts. In the present study, $\mathrm{Ca}^{2+}$ fluorescence intensity in NOS-1 cells cultured with 
$0.1 \mathrm{mM}$ B supplemented medium was significantly lower than that without B. B suppressed the effect of ouabain. These findings clearly demonstrate that NOS-1 cells contains $\mathrm{Na}^{+} / \mathrm{K}^{+}$-ATPase in their cell membranes, and $\mathrm{B}$ stimulates the activity of $\mathrm{Na}^{+} / \mathrm{K}^{+}$-ATPase.

\section{Conclusion}

To the best of our knowledge, this is the first report to demonstrate the acceleration of the $\mathrm{Ca}^{2+}$ influx and efflux by $\mathrm{B}$ supplementation in cultured osteoblastic cells. Moreover, the membrane stabilizing activity of $\mathrm{B}$ was addressed by our findings. Cell membrane stability may be related to the mechanism by which a very low concentration of B promotes the proliferation and differentiation in mammalian osteoblastic cells in vitro.

Acknowledgements All of authors except for the first two authors were actively involved in the execution of the study.

Funding: This study was funded by the Japan Society for the Promotion of Science (JSPS) KAKENHI (Grant Number 25670812).

Conflict of Interest: Author, Yoshihiko Hayashi has received research grants from the JSPS. The authors certify that there are no conflicts of interest to declare.

\section{References}


1. Hunt CD, Nielsen FH (1981) Interaction between boron and cholecalciferol in the chick. In: McCHowell J, Gawthorne JM, White CL (eds) Trace element metabolism in man and animals (TEMA-4), Australia: Australia Academy of science, Canberra, pp 597-600

2. Nielsen FH (1998) The justification for providing dietary guidance for the nutritional intake of boron. Biol Trace Element Res 66(1-3):271-298

3. Nielsen FH (2000) The emergence of boron as nutritionally important throughout the life cycle. Nutrition 16(7-8):512-514

4. Nielsen FH (2004) Dietary fat composition modifies the effect of boron on bone characteristics and plasma lipids in rats. Biofactors 20(3):161171

5. Gallardo-Williams MT, Maronpot RR, Turner CH, Johnson CS, Harris MW, Jayo MJ, Chapin RE (2003) Effects of boric acid supplementation on bone histomorphometry, metabolism, and biomechanical properties in aged female F-334 rats. Biol Trace Element Res 93(1-3):155-170

6. Devirian TA, Volpe SL (2003) The physiological effects of dietary boron. Crit Rev Food Sci Nutr 43(2):219-231

7. Gorustovich AA, Steimetz T, Nielsen FH, Guglielmotti MB (2008) A histomorphometric study of alveolar bone modeling and remodeling in mice fed a boron-deficient diet. 53(7):677-682

8. Brown PH, Bellaloui N, Wimmer MA, Bassil ES, Ruiz J, Hu H, Pfeffer H, Dannel F, Römheld V (2002) Boron in plant biology. Plant Biol 4(2):205223 
9. Gonzalez-Fontes A, Navarro-Gochicoa MT,Camacho-Cristobal JJ, Herrera-Rodrigeuz MB, Quiles-Pando C, Rexach J (2014) Is Ca2+ involved in the signal transduction pathway of boron deficiency? New hypotheses for sensing boron deprivation. Plant Sci 217-218:135-139

10. Sanders D, Pelloux J, Brownlee C, Harper JF (2002) Calcium at the crossroads of signaling. Plant Cell 14(Suppl 1):401-417

11. Dodd AN, Kudla J, Sanders D (2002) The language of calcium signaling. Annu Rev Plant Biol 61:593-620

12. Blastic O, Kudla J (2012) Analysis of calcium signaling pathways in plants. Biochin Biophys Acta 1820(8):1283-1293

13. Su B, Jacinto E, Hihi M, Kallunki T, Karin M, Ben-Neriah Y (1994) JNK is involved in signal integration during costimulation of lymphocytes. Cell 77(5):727-736

14. Egea J, Espinet C, Comella JX (1999) Calcium influx activates extracellular-regulated kinase/mitogen-activated protein kinase pathway through a calmodulin-sensitive mechanism in PC12 cells. J Biol Chem $274(1): 75-85$

15. Apati A, Janossy J, Brozik A, Bauer PI, Magocsi M (2003) Calcium induces cell survival and proliferation through the activation of the MAPK pathway in a human hormone-dependent leukemia cell lone, TF-1. J Biol Chem 278(11):9235-9243

16. Hakki SS, Bozkurt BS, Hakki EE (2010) Boron regulates mineralized tissue-associated proteins in osteoblasts (MC3T3-E1). J Trace Elem Med Biol 24(4):243-250 
17. Ying X, Cheng S, Wang W, Lin Z, Chen Q, Zhang W, Kou D, Shen Y, Cheng X, Rompis FA, Peng L, Lu CZ (2011) Effect of boron on osteogenic differentiation of human bone marrow stromal cells. Biol Trace Elem res $144(1-3): 306-315$

18. Hotta T, Motoyama T, Watanabe H (1992) Three human osteosarcoma cell lines exhibiting different phenotypic expressions. Acta Phatol Jpn $42(8): 595-603$

19. Kawasaki A, Hayashi Y, Yanagiguchi K, Yamada S, Syudo M, Igawa K, Ikeda T, Kubo S, Fujiwara M (2012) Effects of eluted components from 4META/MMA-TBB adhesive resin sealer on osteoblastic cell proliferation. J Dent Sci 7(2):94-98

20. Bolastad BM, Irizarry RA, Astrand M, Speed TP (2003) A comparison of normalization methods for high density oligonucleotide array data based on variance and bias. Bioinformatics 19(2):185-193

21. Quackenbush J (2002) Microarray data normalization and transformation. Nat Genet 32(Supp1):496-501

22. Owen TA, Aronow M, Shalhoub V, Barone LM, Wilming L, Tassinari MS, Kennedy MB, Pockwinse S, Lian JS, Stein GS (1990) progressive development of the rat osteoblast phenotype in vitro: Reciprocal relationships in expression of genes associated with osteoblast proliferation and differentiation during formation of the bone extracellular matrix. J cell Physiol 143(3):420-430

23. Aubin JE, Liu F, Malaval L, Gupta AK (1995) Osteoblast and chondroblast differentiation. Bone 17(2 Suppl): 77S-83S 
24. Lian JB, Stein GS (1995) Development of the osteoblast phenotype: Molecular mechanisms mediating osteoblast growth and differentiation. Iowa Orthop J 15:118-140

25. Duncan RL, Akanbi KA, Farach-Carson MC (1998) Calcium signals and calcium channels in osteoblastic cells. Semin Nephrol 18(2):178-190

26. Yamaguchi DT, Hahn TJ, Iida-Klein A, Kleeman CR, Muallem S (1987) Parathyroid hormone-activated calcium channels in an osteoblast-loke clonal osteosarcome cell line. cAMP-dependent and cAMP-independent calcium channels. J Biol Chem 260(16):7711-7718

27. Lieberherr M (1987) Effects of vitamin $\mathrm{D}_{3}$ metabolites on cytosolic free calcium in conflurnt mouse osteoblasts. J Biol chem. 262(27):1316813173

28. Bidwell JP, Carter WB, Fryer MJ, Health H (1991) Parathyriod hormone (PTH)-induced intracellular $\mathrm{Ca}^{2+}$ signaling in native and PTHdesensitized osteoblast-like cells (POS 17/2.8): pharmacological characterization and evidence for synchronous oscillation of intracellular $\mathrm{Ca}^{2+}$. Endocrinology 129(6):2993-3000

29. Caffrey JM, Farach-Carson MC (1989) Vitamin $\mathrm{D}_{3}$ metabolites modulate dihydropyridine-sensitive calcium currents in clonal rat osteosarcoma cells. J Biol Cem 264(34):20265-20274

30. Civitelli R, Kim YS, Guncten SL, Fujimori A, Huskey M, Avioli LV, Hruska KA (1990) Nongenomic activation of the calcium message by vitamin D metabolites in osteoblast-like cells. Endocrinology $127(5): 2253-2262$ 
31. Duncan RL, Hruska KA, Misler S (1992) Parathyroid hormone activation of stretch-activated cation channels in oesteosarcoma cells (UMR-106.01). FEBS Lett 307(2):219-223

32. Yamaguchi DT, Green J, Kleeman CR, Muallem S (1989) Characterization of volume-sensitive, calcium-permeating pathways in the osteosarcoma cell line UMR-106-01. J Biol Chem 264(8)]4383-4390

33. Meszaros JG, Karin NJ, Frarach-Carson MC (1996) Voltage-sensitive calcium channels in osteoblasts: mediators of plasma membrane signaling events. Connect Tissue Res 35(1-4):107-111

34. Loza JC, Carpio LC, Bradford PG, Dziak R (1999) Molecular characterization of the $\alpha 1$ subunit of the L-type voltage calcium channel expressed in rat calvarial osteoblasts. J Bone Miner Res 14(3):386-395

35. Fleckenstein A (1984) Calcium antagonist: history and prospects for a multifaceted pharmacodynamic principle. In: Opie LH (ed) calcium antagonists and cardiovascular disease. Raven Press, New York, p 9

36. Katz AM, Hager WD, Messineo FC, Pappano AJ (1984) Cellular actions and pharmacology of the calcium channel blocking drugs. Am J Med $77(2 \mathrm{~B}): 2-10$

37. Nishiya Y, Kosaka N, Uchii M, Sugimoto S (2002) A potent 1,4dihudropyridine L-type calcium channel blocker, benidipine, promotes osteoblast differentiation. Calcif Tissue Int 70(1):30-39

38. Lingrel JB, Kuntzweiler T (1994) $\mathrm{Na}^{+}, \mathrm{K}^{+}$-ATPase. 269(31):19659-19662

39. Xie Z, Askari A (2002) $\mathrm{Na}^{+} / \mathrm{K}^{+}$-ATPase as asignal transducer. Eur $\mathrm{J}$ Biochem 269(10):2434-2439 
40. Schwartz A, Grupp G, Wallick E, Grupp IL, Ball WJ Jr (1988) Role of the $\mathrm{Na}^{+} \mathrm{K}^{+}$-ATPase in the cardiotonic action of cardiac glycosides. $268 \mathrm{~B}: 321-338$

41. Ajera T, NG YC (1991) Digitalis sensitivity of $\mathrm{Na}^{+}, \mathrm{K}^{+}$-ATPase, myocytes and heart. Life Sci 48(2):97-106

Figure Captions 
Fig. 1 Real-time PCR reactions for 4 mineralization-related genes, ALP, OPN, OCN, and BSP. Each bar represents the standard deviation of triplicate samples.

Fig. 2 Real-time PCR reactions for 5 genes related to proliferation and differentiation, CFDP1, SDF4, MAP2K1, CTNNA1, and COL1A1. Each bar represents the standard deviation of triplicate samples.

Fig. 3 A typical example of the $\mathrm{Ca}^{2+}$ influx after pretreatment with nifedipine in the experimental group. (a) Fluo 4-AM fluorescence from the cells, $1 \mathrm{~min}$ before B supplementation [red arrow in (d)]. (b) Fluorescence from the same cells, 0 min after B supplementation [yellow arrow in (d)]. (c) Fluorescence from the same cells, 1 min after B supplementation [green arrow in (d)]. Scale bar $=20 \mu \mathrm{m}$. (d) The curve of fluorescent signal intensity with time (calculated slope after B supplementation: 0).

Fig. 4 A typical example of the $\mathrm{Ca}^{2+}$ influx without pretreatment of nifedipine (control group). (a) Fluo 4-AM fluorescence from the cells, 1 min before B supplementation [red arrow in (d)]. (b) Fluorescence from the same cells 0 min after B supplementation [yellow arrow in (d)]. (c) Fluorescence from the same cells, 1 min after B supplementation [green arrow in (d)]. Scale bar $=$ $20 \mu \mathrm{m}$. (d) The curve of fluorescent signal intensity with time (calculated slope after B supplementation: 2).

Fig. 5 A typical example of the $\mathrm{Ca}^{2+}$ efflux after culture with $\mathrm{B}$ in the experimental group. (a) Fluo 4-AM fluorescence from the cells, 0 min after ouabain pretreatment. (b) Fluorescence from same cells after $10 \mathrm{~min}$. Scale 
bar $=20 \mu \mathrm{m}$. (c) The curve of fluorescent signal intensity with time (calculated slope for $10 \mathrm{~min}: 3$ ).

Fig. 6 A typical example of the $\mathrm{Ca}^{2+}$ efflux after culture without $\mathrm{B}$ in the control group. (a) Fluo 4-AM fluorescence from the cells, 0 min after ouabain pretreatment. (b) Fluorescence from the same cells after $10 \mathrm{~min}$. Scale bar $=$ $20 \mu \mathrm{m}$. (c) The curve of fluorescent signal intensity with time (calculated slope for $10 \min : 5)$. 
Table 1

\begin{tabular}{lll}
\hline Gene name & & Oligonucleotides \\
\hline Alkaline phosphatase (ALP) & Forward & CAACCCTGGGGAGGAGAC \\
& Reverse & GCATTGGTGTTGTACGTCTTG \\
Osteopontin (OSP) & Forward & TCACCTGTGCCATACCAGTTAA \\
Osteocalcin (OCN) & Reverse & TGAGATGGGTCAGGGTTTAGC \\
& Forward & GCAAAGGTGCAGCCTTTGTG \\
Bone sialoprotein (BSP) & Reverse & GGCTCCCAGCCATTGATACAG \\
& Forward & TTCCAGTTCAGGGCAGTAGTG \\
GAPDH & Reverse & CCATAGCCCAGTGTTGTAGCA \\
& Forward & TCAGCAATGCCTCCTGCAC \\
& Reverse & TCTGGGTGGCAGTGATGGC \\
\hline
\end{tabular}

Table 2

\begin{tabular}{lll}
\hline Gene name & & Oligonucleotides \\
\hline Craniofacial development protein 1 (CFDP1) & Forward & GCTTCCTCAATGATGTGG \\
Stromal cell derived factor 4 (SDF4) & Reverse & CTTCAGTCTCCTCTCCTTT \\
Mitogen-activated protein kinase kinase 1 (MAP2K1) & Forward & GGAGAGCAAGACACACTT \\
& Reverse & TTCACCTTATACTCGTCCC \\
Catenin alpha 1 isoform (CTNNA1) & GGATACTTAGTGGTATGTCTCTT \\
& Reverse & ACAGCATTGGTACTTGGATA \\
Collagen type 1 alpha 1 (COL1A1) & Forward & GTTAGACTGCCGATTCTG \\
& Reverse & TGTTAAATCAGCACTTCAT \\
GAPDH & Forward & GCTGTCTTATGGCTATGATGAG \\
& Reverse & CACGAGGACCAGAGGGAC \\
& Forward & CCATGGAGAAGGCTGGGG \\
& Reverse & CAAAGTTGTCATGGATGACC \\
\hline
\end{tabular}




\section{Table 3}

\begin{tabular}{llll}
\hline Gene name & Z score & Ratio $^{\mathrm{a}}$ & Confirmation $^{\mathrm{b}}$ \\
\hline Craniofacial development protein 1 (CFDP1) & 2.5 & 1.4 & 2.1 \\
Stromal cell derived factor 4 (SDF4) & 3.5 & 1.3 & 1.5 \\
Mitogen-activated protein kinase kinase 1 (MAP2K1) & 2.7 & 1.1 & 1.9 \\
Catenin alpha 1 isoform (CTNNA1) & 2.1 & 1.1 & 1.8 \\
Collagen type 1 alpha 1 (COL1A1) & 3.6 & 1.1 & 1.3 \\
\hline
\end{tabular}

${ }^{a}$ The fold-change in the raw signal intensities

${ }^{\mathrm{b}}$ Confirmed by the quantitative polymerase chain reaction data (data from triplicate samples) 
Fig. 1

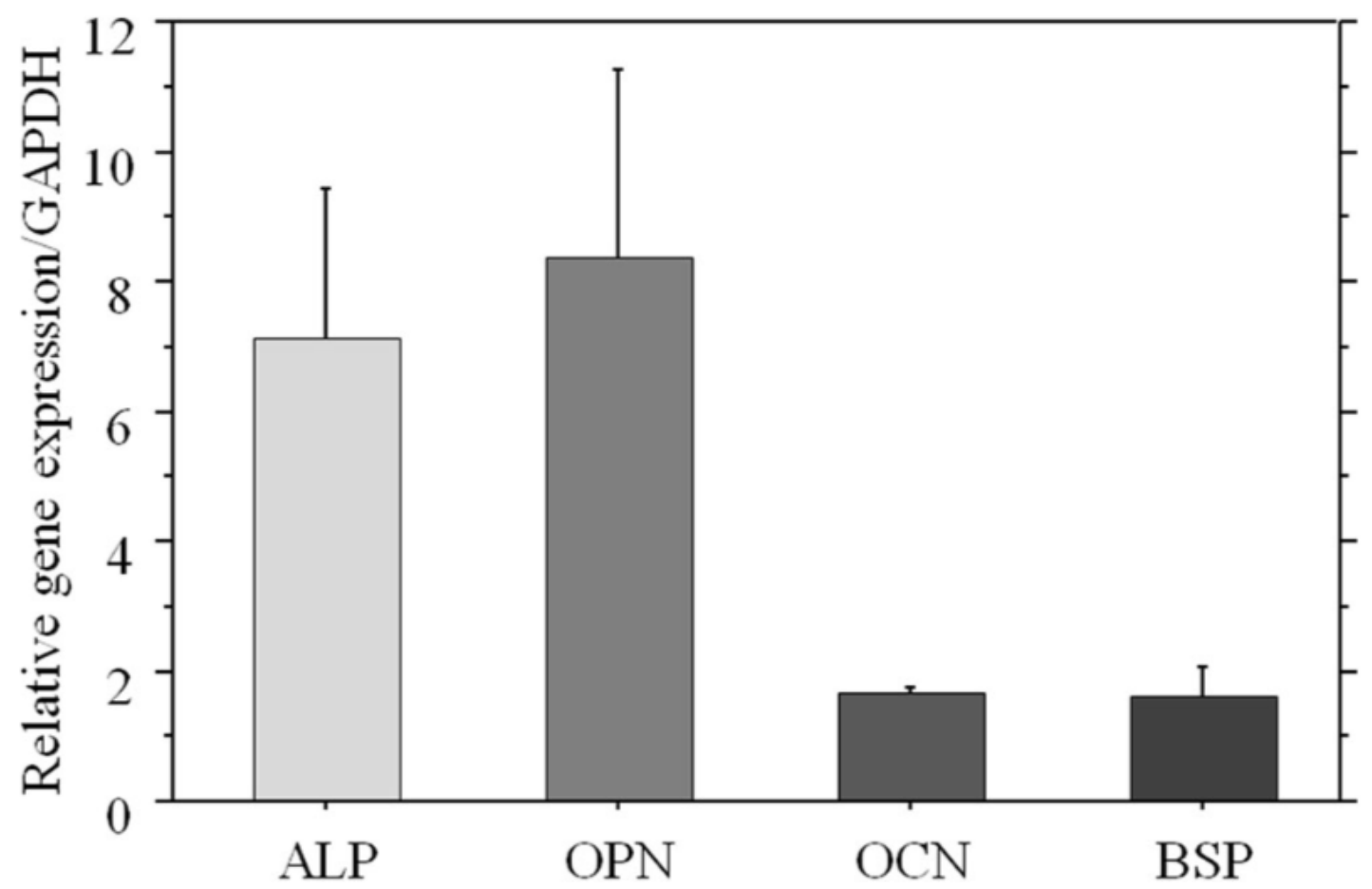

Fig. 2

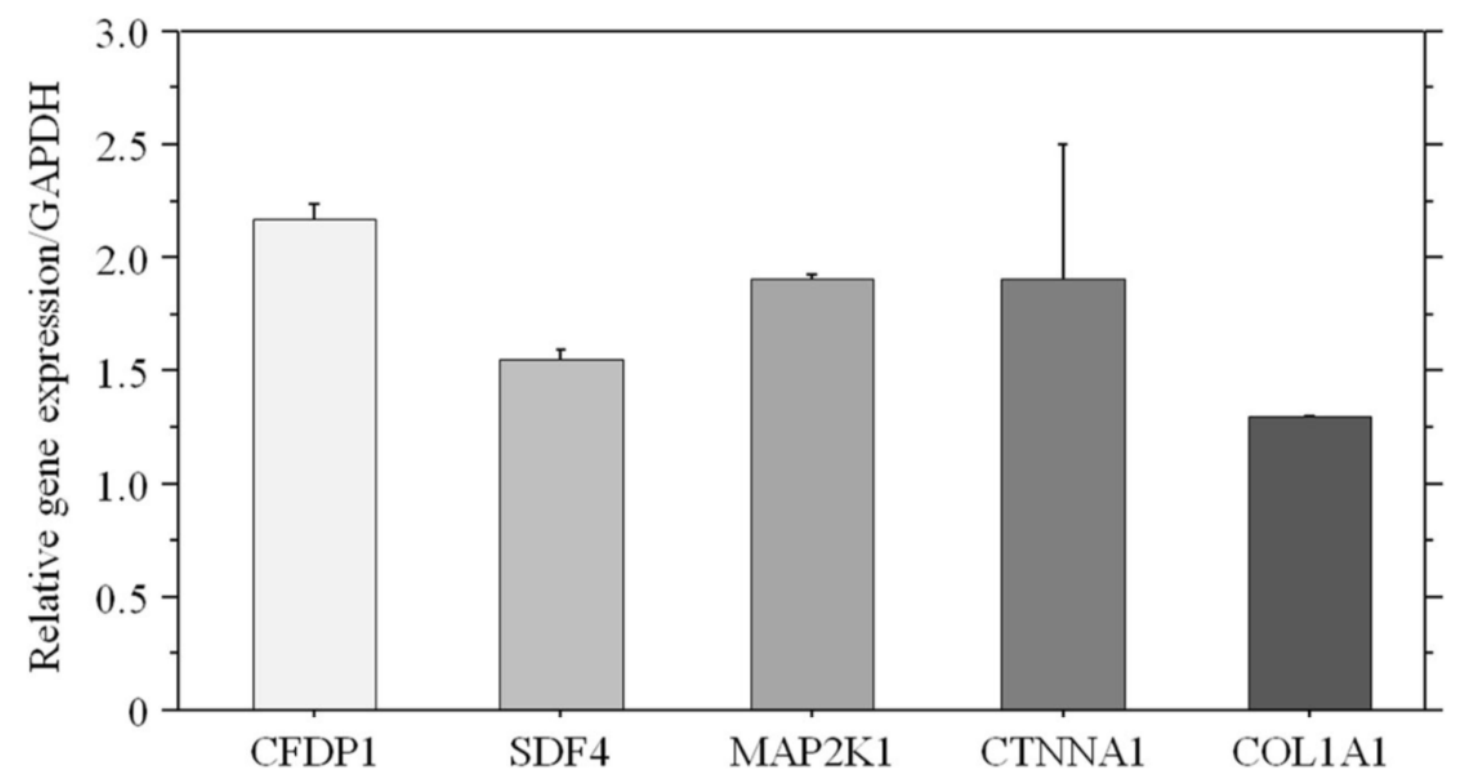


Fig. 3
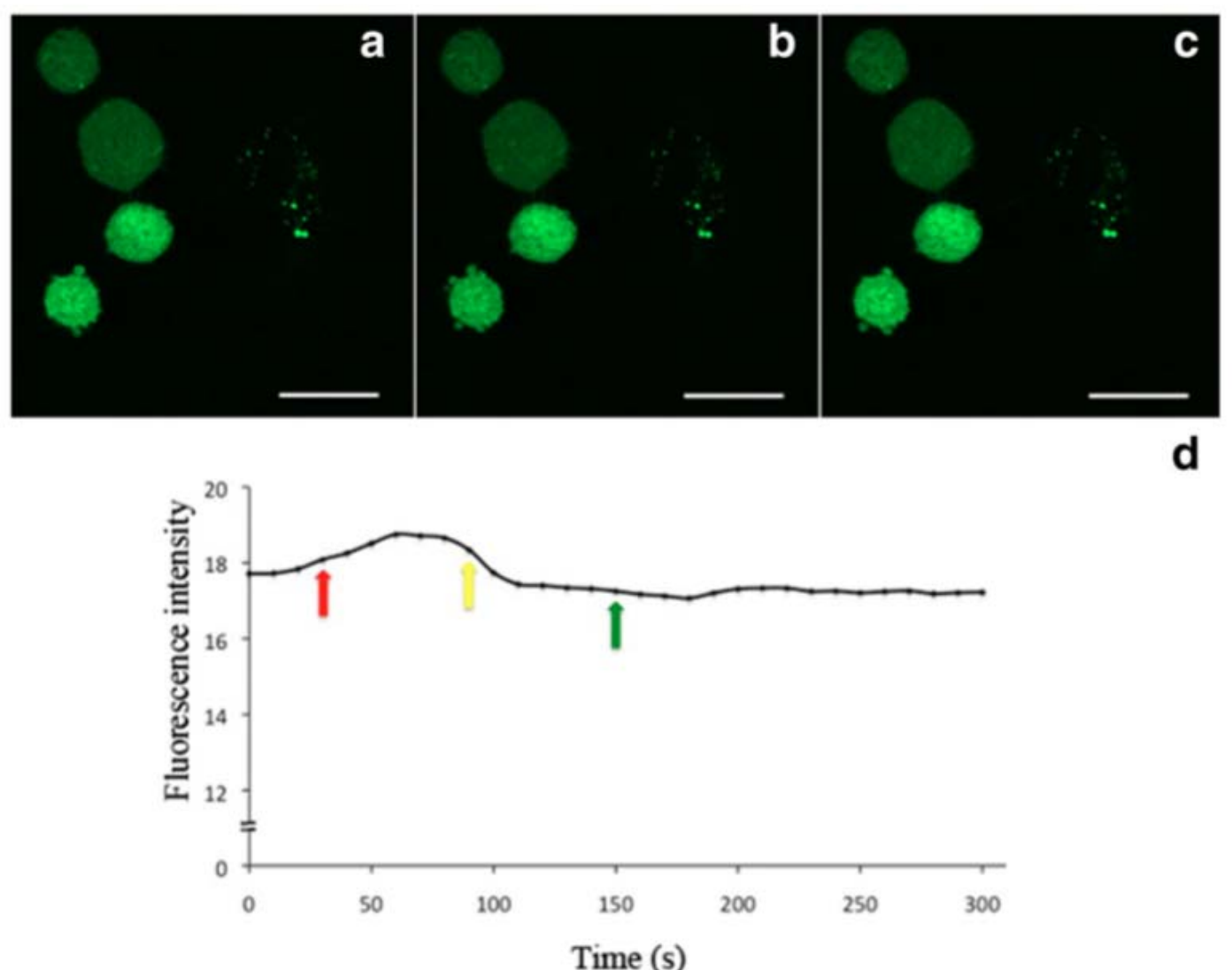
Fig. 4
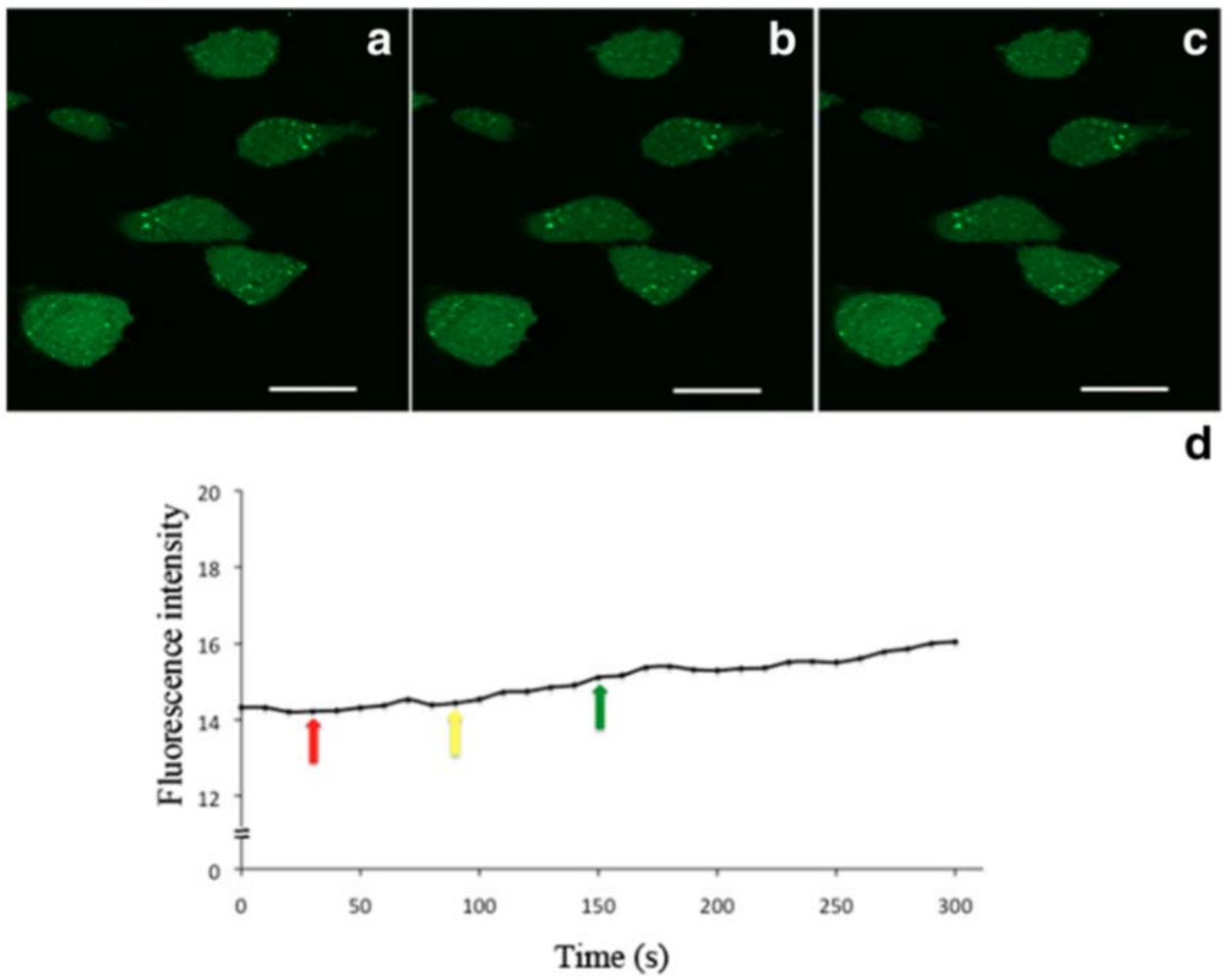
Fig. 5

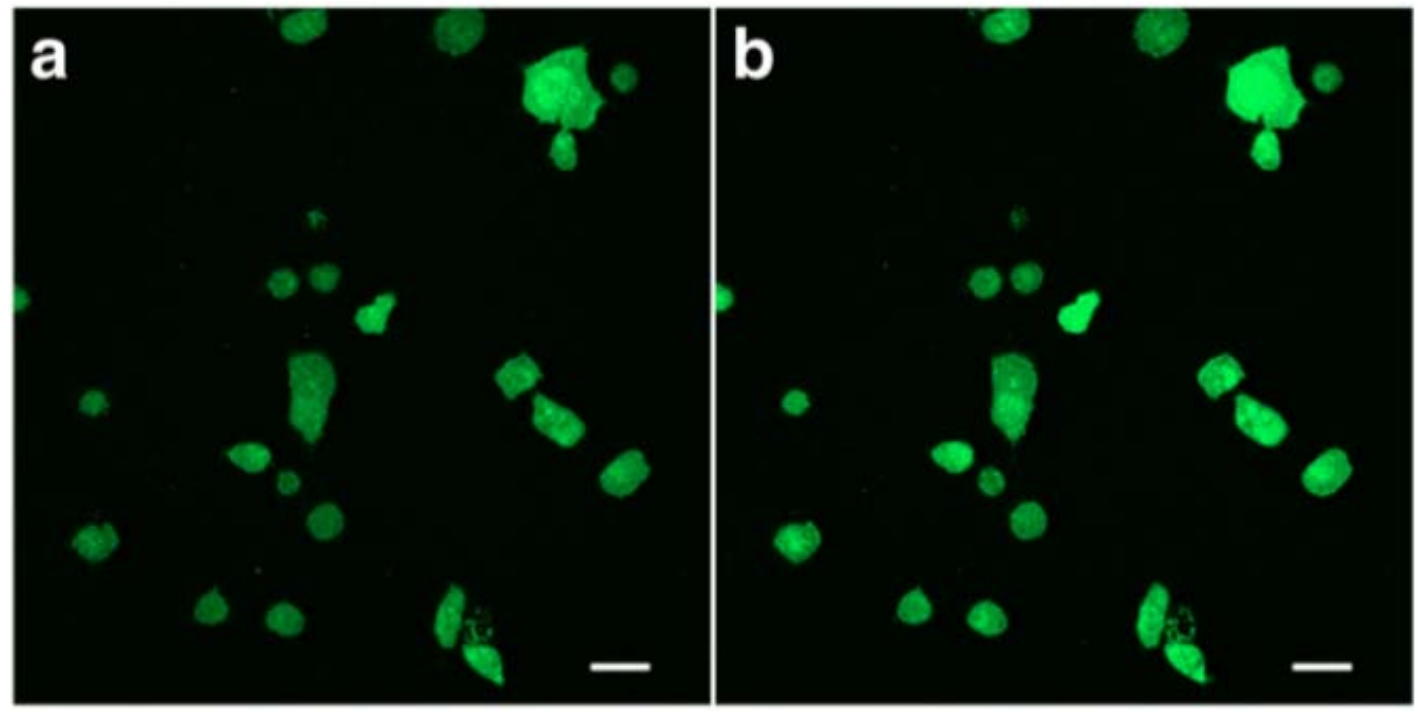

C

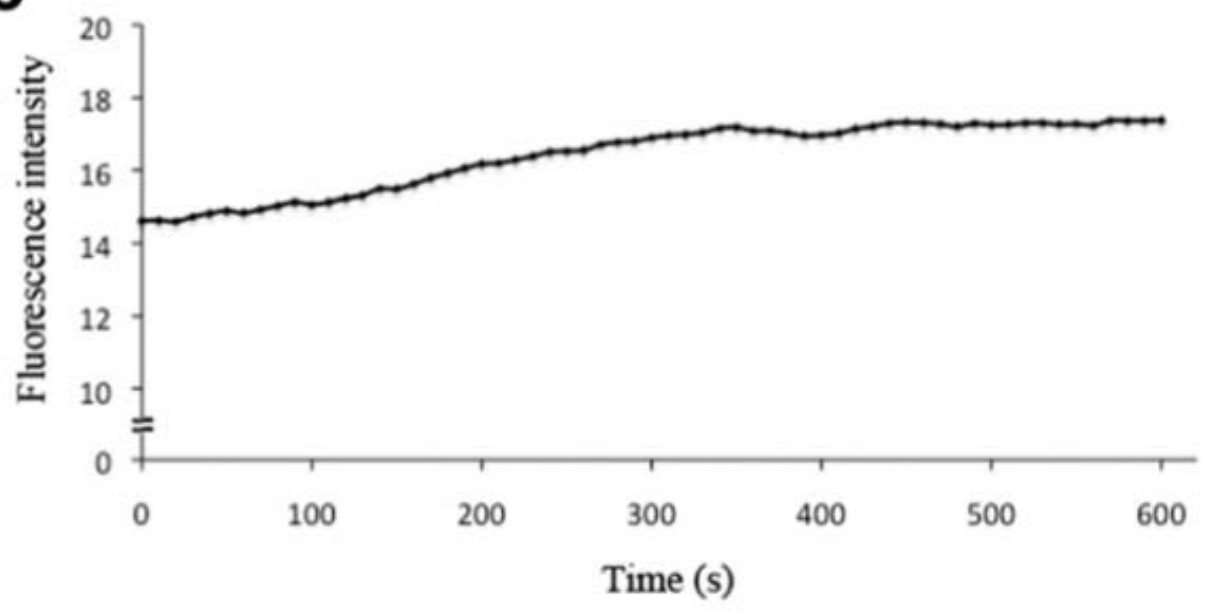


Fig. 6

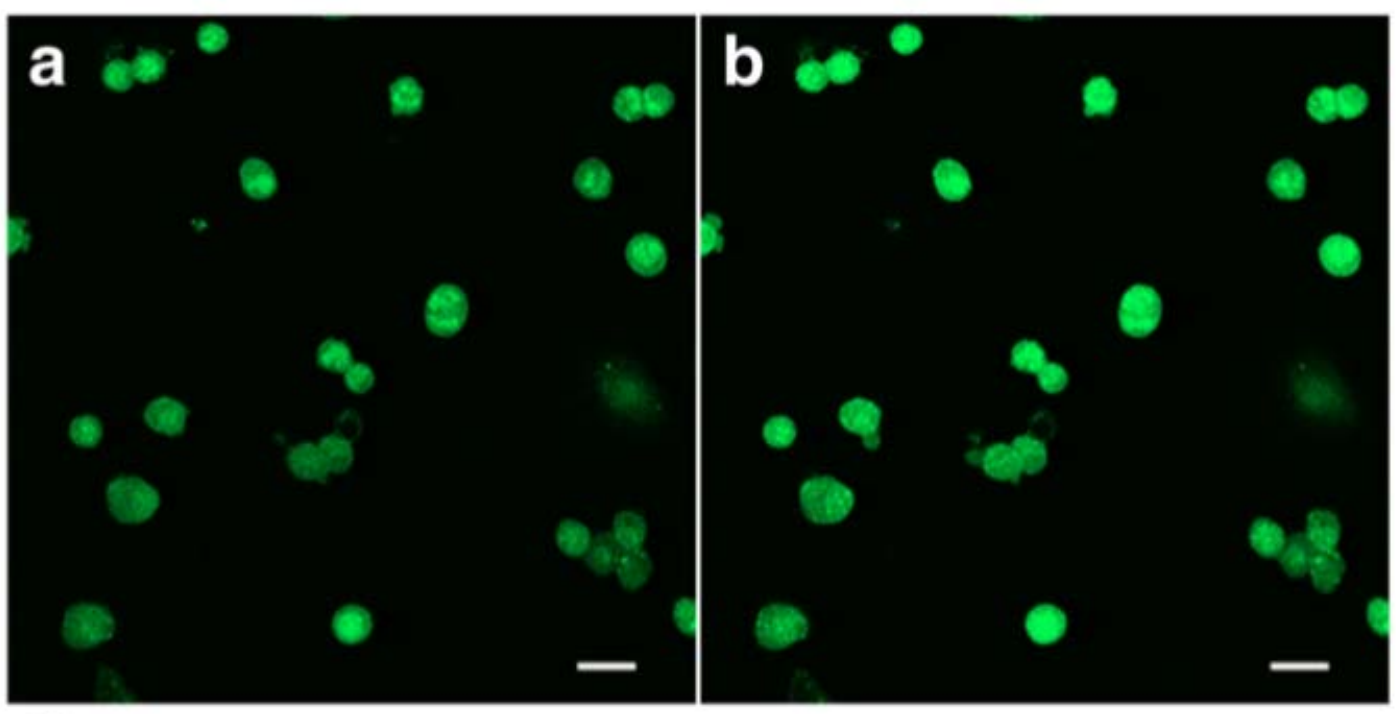

\section{C}

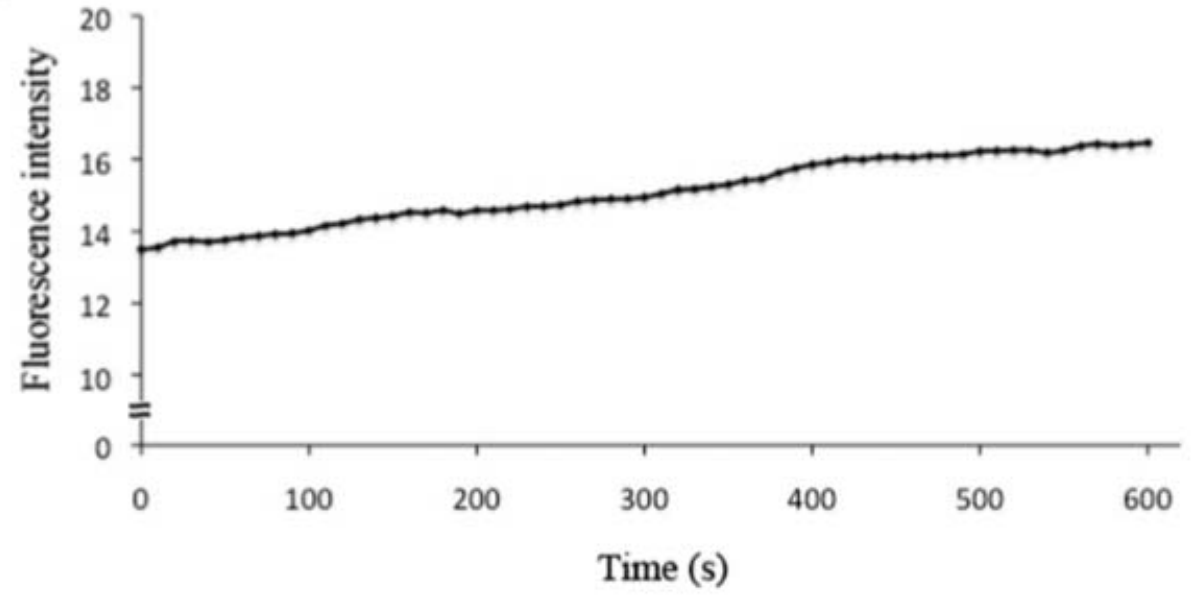

